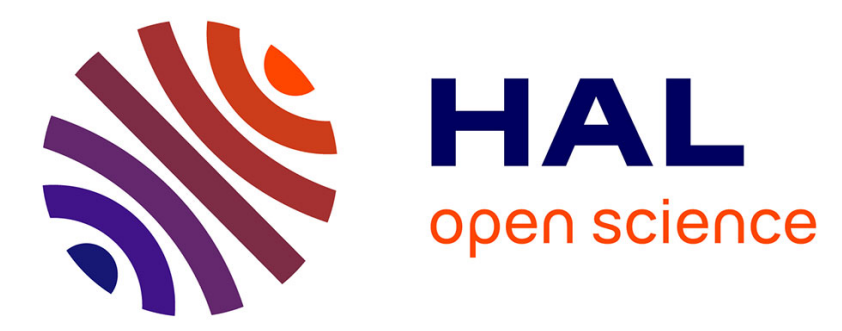

\title{
An Investigation on Implemented Actions to Improve Responsiveness in Manufacturing Firms
}

Alessia Napoleone, Marco Macchi, Alessandro Pozzetti

\section{To cite this version:}

Alessia Napoleone, Marco Macchi, Alessandro Pozzetti. An Investigation on Implemented Actions to Improve Responsiveness in Manufacturing Firms. IFIP International Conference on Advances in Production Management Systems (APMS), Sep 2017, Hamburg, Germany. pp.184-192, 10.1007/9783-319-66926-7_22. hal-01707273

\section{HAL Id: hal-01707273 \\ https://hal.inria.fr/hal-01707273}

Submitted on 12 Feb 2018

HAL is a multi-disciplinary open access archive for the deposit and dissemination of scientific research documents, whether they are published or not. The documents may come from teaching and research institutions in France or abroad, or from public or private research centers.
L'archive ouverte pluridisciplinaire HAL, est destinée au dépôt et à la diffusion de documents scientifiques de niveau recherche, publiés ou non, émanant des établissements d'enseignement et de recherche français ou étrangers, des laboratoires publics ou privés. 


\title{
An investigation on implemented ac- tions to improve responsiveness in manufacturing firms
}

\author{
Napoleone A. ${ }^{1}$, Macchi M. ${ }^{1}$, and Pozzetti A. ${ }^{1}$ \\ Department of Management, Economics and Industrial Engineering, \\ Politecnico di Milano, Milano, Italy \\ Alessia.napoleone@polimi.it
}

\begin{abstract}
The unpredictability of market requirements is currently challenging manufacturing firms in addressing the need to be more and more responsive. To meet this need and to gain competitive advantage firms require reconfigurability. Literature provides much information on characteristics of reconfigurability, but generally restricting the focus on highly automated systems. In order to investigate on reconfigurability characteristics in a broader context, within this paper, three cases of plant reconfiguration were analysed and implemented actions were interpreted via the core characteristics of reconfigurability. Results allow fostering an extension of definitions of such core characteristics with respect to what stated by literature.
\end{abstract}

Keywords: reconfiguration, systemic approach, modularity, integrability, convertibility

\section{Introduction}

Nowadays, manufacturing firms need to survive in the current context characterized by unpredictable and frequent market changes and the demand for products with shortened life cycles [1]. In this scenario, responsiveness is more and more a decisive competitive advantage [2]. Responsiveness is the speed at which a system can meet changing goals at an affordable cost, producing according to new requirements or technology changes [3], [4]. In the interest of being responsive, manufacturing firms need to develop the reconfigurability capability [2], [3], [5], [6], [7], [8], [9].

Reconfigurability is the ability to repeatedly change and/or rearrange the components of a system in a cost-effective way, to meet new environmental and technological changes [10]. Reconfigurability has been associated to Reconfigurable Manufacturing Systems (RMSs), often described by literature as highly automated systems. However, due to the actual evolving context, nowadays reconfigurability should be needed, in a broader way, not only referring to highly automated systems. For example, it could be the case of Small and Medium Enterprises (SMEs), producing customized and low- 
volume products, requiring manual assembly for final phases of the manufacturing process. The objective of this paper is to investigate on characteristics of reconfigurability at firm level through the exploratory and descriptive analysis of three cases.

\section{Literature review on core characteristics of reconfigurability}

According to literature, reconfigurability is composed of six core characteristics: modularity, integrability, diagnosability, scalability, convertibility and customization [6], [7], [4], [11], [3], [12]. According to Bi et al. [13], "Modularity implies that both software and hardware elements are modularized. Scalability means the system is scalable in terms of the product volume. Integrability means the system and system components are designed for both ready integration and future introduction of new technology. Convertibility allows quick changeover between existing products and quick system adaptability for future products. Diagnosability is able to identify quickly the sources of quality and reliability problems that occur in large systems". For Shabaka \& Elmaraghy [15] customized flexibility (i.e. customization) enables cost-effective reconfiguration when product or volume changes are introduced. Hence, customization means the system configurations adapt to changing market requirements.

As observed by Andersen et al. [14], compared to the wide literature treating reconfigurability at system level, a few authors deepened on reconfigurability at firm level. Moreover, literature investigating on core characteristics of reconfigurability at firm level is even scarcer. Wiendahl et al. [16] referred to characteristics of "transformable" factories. However, instead of introducing new definitions, within this paper the possibility to extend at firm level definitions of the six consolidated characteristics was explored. Therefore, the research questions addressed within this paper are the following.

- Can actions of manufacturing firms aimed at improving responsiveness be interpreted by means of reconfigurability?

- When focusing at firm level, can a reconfiguration be interpreted through the six core characteristics of reconfigurability?

\section{Exploratory research}

In order to answer to the research questions, an exploratory and purely descriptive study, focused on manufacturing firms of different sizes, was performed. The cases, selected amongst successful companies in their own market, were three. A brief description of characteristics of analysed cases is provided in Table 1. Due to changed market requirements, i.e. in order to produce evolved product families, the selected cases had to reconfigure their plants. 
Table 1. Summary of characteristics of analysed firms

\begin{tabular}{|c|l|l|l|}
\cline { 2 - 4 } \multicolumn{1}{c|}{} & \multicolumn{1}{c|}{ Firm 1 } & \multicolumn{1}{c|}{ Firm 2 } & \multicolumn{1}{c|}{ Firm 3 } \\
\hline Size ${ }^{1}$ & Small enterprise & Small enterprise & Medium enterprise \\
\hline Product sold & $\begin{array}{l}\text { Food processing machines (the fo- } \\
\text { cus of this paper is on slicers) }\end{array}$ & Taps and fittings & $\begin{array}{l}\text { Hydronic solutions (mainly, valves } \\
\text { and mixers) }\end{array}$ \\
\hline $\begin{array}{c}\text { Main produc- } \\
\text { tion phases }\end{array}$ & $\begin{array}{l}\text { - Machining and tooling } \\
\text { - Manual assembly }\end{array}$ & $\begin{array}{l}\text { - Mechanical processing } \\
\text { - Washing } \\
\text { - Surface treatments } \\
\text { - Manual assembly }\end{array}$ & $\begin{array}{l}\text { - Plastic moulding and brass } \\
\text { moulding } \\
\text { - Mechanical processing } \\
\text { - Manual and automatic } \\
\text { assembly }\end{array}$ \\
\hline $\begin{array}{c}\text { Manufacturing } \\
\text { system }\end{array}$ & $\begin{array}{l}\text { Manufacturing cells. Stations within } \\
\text { the cells exploit machines' multi- } \\
\text { functionality for completing the en- } \\
\text { tire processing of slicers' compo- } \\
\text { nent }\end{array}$ & $\begin{array}{l}\text { Job shop. Three departments } \\
\text { equipped with numerical control } \\
\text { stations and transfer machining } \\
\text { stations }\end{array}$ & $\begin{array}{l}\text { Job shop. Three departments } \\
\text { equipped with numerical control } \\
\text { stations and transfer machining } \\
\text { stations }\end{array}$ \\
\hline $\begin{array}{c}\text { Assembly sys- } \\
\text { tem }\end{array}$ & $\begin{array}{l}\text { Assembly cells. Each cell is respon- } \\
\text { sible for the assembly of a certain } \\
\text { product family }\end{array}$ & $\begin{array}{l}\text { Assembly cells. Each cell is respon- } \\
\text { sible for the assembly of a certain } \\
\text { product family }\end{array}$ & $\begin{array}{l}\text { Assembly cells. Each cell is respon- } \\
\text { sible for the assembly of a certain } \\
\text { product family }\end{array}$ \\
\hline
\end{tabular}

The methodology required (i) visiting plants, and, at the time of the visit, (ii) asking experts, with long experience in the studied firms, to show and explain the main actions implemented on processes to face substantial changes in market requirements. Thus, questions were formulated about plant changes, their causes and consequences, the exploited actions, criticalities and solutions.

The focus of the following analysis of cases is on implemented actions at multiple levels, i.e. firm, production system (or production departments) and station ones. The interpretation of actions was driven by the knowledge of the core characteristics' definitions, researching traces of reconfigurability aspects. Whenever actions have been associated to core characteristics, it has been clearly stated within the analysis.

\subsection{Firm 1}

In order to reconfigure processes according to changed market requirements, Firm 1 adopts a systemic approach at firm level. Indeed, when required, the general manager meets all functions (i.e. production, purchasing, and research \& development functions), in order to make joint decisions related to lower levels. Consequently, the systemic approach - by means of the inter-functional meetings at firm level - has an impact on subsequent actions taken at production system level, i.e. related to both machining and assembly systems.

The product and process engineering integration is another example of systemic approach. Such integration led Firm 1 to actions of process standardization at the machining phase and actions of postponement of customized activities at the assembly phase. Thus, the firm selected machining processes that, even if not efficient for the singlepiece processing, are adaptable - as they are general purpose for the capability of operations - for the whole (wider, compared to the past) production mix. Other activities, previously performed at the machining phase for efficiency purposes, were postponed at the assembly phase for customization purposes. To summarise, they moved and

1 According to the European Commission 
sometimes converted activities for the systemic goal of producing an increased variety of products.

At the manual assembly phase, each cell can be considered as a module of the assembly phase; indeed, each cell has a consolidated way of working, cells are "self-organized". Again, according to the systemic approach, to face changes, the firm formed operators to be polyvalent, allowing some freedom in changing their tasks, thus gaining in stations convertibility (whenever a new product family is introduced). However, due to market unexpected changes, recently, they have often been forced to move more than one operator from one cell to another. Such intervention perturbs the consolidated way of working of cells and, often, operators resistance to change emerges. Indeed, this cultural aspect is certainly an obstacle to stations convertibility. In this regard, one interesting operational matter is worth of a remark: the fact that operators, when assigned to new/changed products with higher throughput, still tend to preserve the pace of the old product, thus leading to a throughput loss. It is clearly an effect of people difficulty in converting to the new pace; this behaviour is probably reinforced by the "self-organization" within the cell (that is somehow a soft aspect within the module).

\subsection{Firm 2}

Within Firm 2, mechanical processing, washing, surface treatments, and manual assembly can be seen as functional production modules (autonomous and independent) and physical production modules (performed in different buildings). This modularity allows managers of Firm 2 best addressing reconfiguration actions, really focusing on specific needs (i.e. at department level). Nonetheless, even if modules are independent, the fact that they have to work together in a system is critical. Therefore, in order to ensure that process modules have also specific roles in achieving goals at the entire firm level, one of their most important decisions was adopting a systemic approach. Indeed, Firm 2 improved the coordination of such modules, by renewing the intermediate warehouse. In this building, components coming from the washing and surface treatment departments are stored, before the manual assembly. Indeed, the warehouse is a relevant element for coordination: with this regard, they also decided to implement an integrated software, capable to manage and coordinate products' flows and people activities; it allows picking - in the warehouse - the right part at the right moment in order to make the required tasks and move forward production, according to customer demand.

Regarding changes related to the individual production processes, they mainly acted on mechanical processing and washing systems.

At the mechanical processing phase, their systemic approach, enabled by a close collaboration with a technology provider, allowed converting the mechanical processing system. Before changes, they had anthropomorphic robots feeding highly productive machines. To do so, they had to deal with a machines' interoperability problem: the production manager said that, before then, they aimed at buying "machines"; whereas, from then on, they understood the importance of creating "a system" and not "a set of different machines".

At the washing phase, they deeply changed the washing department, again thanks to a close collaboration with a technology provider, by creating an automated "system" (in 
other words, they took an action of systemic automation, not mere department automation, meaning that - as systemic - the whole production logistics for the washing phase was considered). To ensure the systemic automation of the phase, they had to provide both robot and equipment with interoperability, exploiting the collaboration with the technology provider.

The main obstacle dealt with by firm 2 was related to operators: changing departments unavoidably changed their way of working. Indeed, convertibility problems were not related to required competences, but to the need to deal with their resistance to change. The firm was able to face this problem because the aforementioned adjustments of departments allowed reassigning and valorising professional roles, also thanks to improved working conditions. Thus, they motivated operators, somehow involving them in the change process, by giving them the opportunity to have a professional growth.

\subsection{Firm 3}

The focus of the analysis of Firm 3 is on mechanical and assembly processes, because they underwent a major reorganization to accomplish changed market requirements. To face changes, they adopted a systemic approach, by improving the coordination and communication of all departments (seen as component modules of the whole production system). This action allows finding appropriate solutions for the whole firm, not just for one or few departments. In order to do so, they acted on two levers. Firstly, they decided to implement a Manufacturing Execution System (MES), which allowed having real-time information about individual stations. Having every single station under control allowed shaping improvement actions (or conversions of the production system) in the most appropriate way, thus increasing firm responsiveness. Secondly, they modified the process engineering function. According to the production manager, before this action, each department (or module) was "self-organized" and dealing with its own problems, without any external support. Today the situation is different because the process engineering function gathers feedback directly from the field, putting together needs and problems of different departments (i.e. the modules of the production system).

Regarding changes related to individual production processes, each intervention was appropriately designed: they are gradually changing (converting) departments, thus the integration with additional modules is planned ahead. At this moment, they are mainly acting on mechanical processing. However, they are planning to act on assembly, too. As they are more advanced in converting the mechanical processing phase, this phase is the main focus considered in this paper. Therein, they are taking two actions of systemic automation. (i) They are replacing transfer lines, capable to ensure high volumes and low variety, with new flexible manufacturing lines, with longer cycle times but ensuring higher variety. Since the integrability of lines with additional modules is planned ahead, they are creating a system that, gradually, will be completely automated even for machines' loading and unloading, leading to the possibility of continuously producing and providing the greater variety required by the market. (ii) Within the washing area, four people involved in the cleaning of pieces have been replaced by the introduction of an automated and smart system. Thus, also in this area, they did not 
simply introduce a machine, but exploiting integrability of stations, they created a system, designed to be further automated in future, by automatizing also the loading and unloading of pieces.

To implement the aforementioned actions, high skilled operators will progressively replace low skilled operators. In fact, the capability to manage complex systems will be more and more required. The product manager pointed out that the main problem they are dealing with is "changing human resources ways of working". They are positively dealing with such problem by involving people (by asking for suggestions and ideas) in the change process.

\section{Discussion}

This paper is an investigation on implemented actions to adapt configurations of production systems to market changes. The aim is to explore reconfigurability characteristics at firm level. The results can be summarised in three main categories of actions and good practices taken by firms. These actions (i.e. systemic approach, modularisation and conversions) are reported and detailed in Table 2.

Table 2. Actions and good practices taken by firms

\begin{tabular}{|c|c|c|c|}
\hline & Systemic approach & Modularisation & Conversions \\
\hline$\sum_{\frac{\infty}{4}}^{+1}$ & $\begin{array}{l}\text { Making joint decisions } \\
\text { - Integrating product and process engineering } \\
\text { Exploiting operators polyvalence }\end{array}$ & $\begin{array}{l}\text { Self-organized systems or stations } \\
\text { composed of machines and human re- } \\
\text { sources }\end{array}$ & $\begin{array}{l}\text { - Process standardization actions } \\
\text { - Changes of operators roles }\end{array}$ \\
\hline & $\begin{array}{l}\text { Making joint decisions } \\
\text { - Introducing management and coordination } \\
\text { software systems } \\
\text { - Collaborating with technology providers to } \\
\text { solve interoperability problems } \\
\text { - Introducing systemic automation } \\
\text { - Involving operators in the change process } \\
\end{array}$ & $\begin{array}{l}\text { Departments as autonomous and in- } \\
\text { dependent production modules }\end{array}$ & $\begin{array}{l}\text { Changes of operators roles } \\
\text { Actions accurately shaped according to } \\
\text { heeds of given and well-defined modules } \\
\text { - Introducing systemic automation }\end{array}$ \\
\hline & $\begin{array}{l}\text { Making joint decisions } \\
\text { - Integrating product and process engineering } \\
\text { - Introducing management and coordination } \\
\text { software systems } \\
\text { - Collaborating with technology providers to } \\
\text { solve interoperability problems } \\
\text { - Introducing systemic automation } \\
\text { - Involving operators in the change process }\end{array}$ & $\begin{array}{l}\text { Self-organized systems or stations } \\
\text { composed of machines and human re- } \\
\text { sources }\end{array}$ & $\begin{array}{l}\text { - Changes of operators roles } \\
\text { Introducing systemic automation }\end{array}$ \\
\hline
\end{tabular}

Firstly, to be effective, the actions taken at a certain production level (i.e. station, system and firm levels) should take into account the goal of the upper production level. In other words, the systemic approach drives individual modules (located at certain production levels) in having a role for achieving a systemic objective, otherwise not perceived by modules. Secondly, exploited at different production levels, modularisation supported in achieving responsiveness. Thirdly, conversion actions are evident in all firms, and they are manifestly related to the previous two categories.

In each of the three cases, the exploitation of the systemic approach at different production levels enabled convertibility that, in turn, allowed the firm to deal with the need to meet changed market requirements. For instance, actions of systemic automation (firms 
2 and 3) accomplished conversions in terms of functionality of individual stations and, thus, systems.

Moreover, modularity had an impact on convertibility, both in a positive and a negative sense. On the one hand, modularity simplified the identification of specific problems and, thus, allowed shaping the most appropriate solutions. On the other hand, the resistance to changes of human resources is an effect having self-organized systems (modules) and, within cases, it was an obstacle to convertibility. Furthermore, while firm 1 is currently unable to deal with resistance to changes, in firms 2 and 3 this problem was overcome through a systemic approach (even in this example, the systemic approach was enabler of conversions). More precisely, in firm 2, operators were made aware of the possibility of having a professional growth; in firm 3, operators were engaged in the change process by promoting their new role in meeting systemic goals.

\section{Conclusions}

When referring to the characteristics of reconfigurability at firm level, modularity is an important one. In fact, each specific module has its role within a larger system, composed of many other modules. The set of these modules have to work together for a systemic objective. In other words, modules need to be integrated with each other in order to obtain a systemic functionality, useful for a certain systemic objective. Thus, also developing the systemic view is an important characteristic of reconfigurability and could be reasonably associated to the characteristic of integrability. In fact, in compliance with the aforementioned definitions provided by literature, integrability is closely related to modularity. More precisely, deductions from the analysed cases allow supposing that soft aspects of integrability should be reasonably considered, thus fostering an extension of the definition of integrability at firm level.

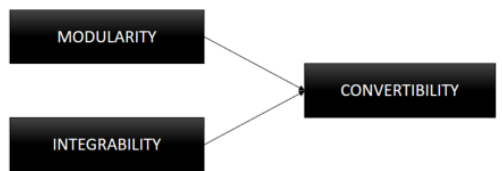

Fig. 1. An attempt to describe reconfigurations made in the three cases through some of the core characteristics of reconfigurability

Due to the contextual and internal characteristics of analysed cases, within this paper, scalability and diagnosability were not investigated. Moreover, some scarce insights on customization were gathered, not allowing making relevant observations. Thus, further research is required. However, a preliminary answer to the research question is provided in the above figure (Figure 1). Modularity, integrability and convertibility characteristics seem useful to describe a reconfiguration at firm level, widening the focus beyond highly automated systems. Moreover, the studied characteristics allowed the three firms to reconfigure their processes according to new market requirements thanks to the game of relationships among them (as shown in figure 1). Therefore, not only 
characteristics, but also their relationships are worth of further research. Concluding, this paper relies on the assumption that reconfigurability is sufficient to ensure responsiveness, however further research aimed at measuring the effects of reconfigurability on responsiveness improvement should be performed.

\section{References}

1. Y. Koren, W. Wang, and X. Gu, "Value creation through design for scalability of reconfigurable manufacturing systems," Int. J. Prod. Res., pp. 1-16, 2016.

2. A. M. Shaik, V. V. S. K. Rao, and C. S. Rao, "Development of modular manufacturing systems - a review," Int. J. Adv. Manuf. Technol., vol. 76, no. 5-8, pp. 789-802, 2014.

3. Y. Koren and M. Shpitalni, "Design of reconfigurable manufacturing systems," J. Manuf. Syst., vol. 29, no. 4, pp. 130-141, 2010.

4. M. G. Mehrabi, A. G. Ulsoy, and Y. Koren, "Reconfigurable manufacturing systems : Key to future manufacturing," J. Intell. Manuf., vol. 11, pp. 403-419, 2000.

5. M. R. Abdi, "Layout configuration selection for reconfigurable manufacturing systems using the fuzzy AHP," Int. J. Manuf. Technol. Manag., vol. 17, no. 1, pp. 149-165, 2009.

6. Y. Koren, "General RMS Characteristics. Comparison with Dedicated and Flexible Systems," in Chapter 3., no. 1, 2006, pp. 27-44.

7. A. M. Deif and H. A. ElMaraghy, "Assessing capacity scalability policies in RMS using system dynamics," Int. J. Flex. Manuf. Syst., vol. 19, no. 3, pp. 128-150, 2008.

8. K. Gumasta, S. Kumar Gupta, L. Benyoucef, and M. K. Tiwari, "Developing a reconfigurability index using multi-attribute utility theory," Int. J. Prod. Res., vol. 49, no. 920315198, pp. 1669-1683, 2011.

9. K. K. Goyal, P. K. Jain, and M. Jain, "A comprehensive approach to operation sequence similarity based part family formation in the reconfigurable manufacturing system," Int. J. Prod. Res., vol. 51, no. 6, pp. 1762-1776, 2013.

10. C. Rösiö, Supporting the design of reconfigurable production systems, no. 130. 2012.

11. H. A. ElMaraghy, "Flexible and reconfigurable manufacturing systems paradigms," Int. J. Flex. Manuf. Syst., vol. 17, no. 4 SPECIAL ISSUE, pp. 261-276, 2006.

12. G. X. Wang, S. H. Huang, Y. Yan, and J. J. du, "Reconfiguration schemes evaluation based on preference ranking of key characteristics of reconfigurable manufacturing systems," Int. J. Adv. Manuf. Technol., pp. 1-19, 2016.

13. Z. M. Bi, S. Y. T. Lang, W. Shen, and L. Wang, "Reconfigurable manufacturing systems: the state of the art," Int. J. Prod. Res., vol. 46, no. 4, pp. 967-992, 2008.

14. A.-L. Andersen, T. D. Brunoe, and K. Nielsen, "Reconfigurable Manufacturing on Multiple Levels: Literature Review and Research Directions.," in Advances in Production Management Systems: Innovative Production Management Towards Sustainable Growth, 2015, pp. 266-273.

15. A. I. Shabaka and H. A. Elmaraghy, "Generation of machine configurations based on product features," Int. J. Comput. Integr. Manuf., vol. 20, no. 4, pp. 355-369, 2007.

16. H. P. Wiendahl, H. A. ElMaraghy, P. Nyhuis, M. F. Zah, H. H. Wiendahl, N. Duffie, and M. Brieke, "Changeable Manufacturing - Classification, Design and Operation," CIRP Ann. - Manuf. Technol., vol. 56, no. 2, pp. 783-809, 2007. 